\title{
Why four Gospels? Why only four?
}

\author{
James Dunn
}

Professor Jimmy Dunn is Lightfoot Professor Emeritus of Divinity at the University of Durham, and a Methodist local preacher. His many books include a three-volume history of the first 120 years of the faith (Christianity in the Making trilogy), and commentaries on Romans, Galatians, and Colossians and Philemon.

j.d.g.dunn@btopenworld.com

Chichester, UK

This is a transcript of the 2016 Fernley-Hartley Lecture, which was delivered during the 2016 British Methodist Conference at the Lambeth Mission, London, and is published here with acknowledgement to the Fernley-Hartley Trust. It stands largely unchanged from its first delivery in the hope that the texture and tone of the lecture might also be retained. The article argues that answering the questions 'Why four Gospels?' and 'Why only four?' provides a clear picture of the character of the gospel of Jesus as 'the same yet different', as well as a challenge to today's Christians to retell the good news in their own contexts with equal or equivalent effect. The article discusses the context in which the four canonical Gospels were recognised, pointing out that the term 'gospel' was coined in the process. The distinctive emphases of the Synoptics and John show how the same story can be told differently, an essential restatement of the same message for new and changing audiences.

NEW TESTAMENT STUDIES • GOSPELS • SYNOPTICS • CANON • APOCRYPHA 
Why four Gospels? Why only four? These were not questions which troubled John Wesley. For him a more pressing question was how to relate the gospel and the law: whether the law should always be preached first, to make an audience conscious of their sin and need, prior to the preaching of the gospel. ${ }^{1}$ But 'Why four Gospels?' and 'Why only four?' are questions that need to be asked today - and given a firm and clear answer.

The questions arise because we know that there were more than four Gospels written in early Christianity. J. K. Elliott, in his collection of documents making up The Apocryphal New Testament, ${ }^{2}$ lists what some may regard as an amazing collection, including: the Jewish-Christian Gospels (the Gospel according to the Hebrews, the Gospel of the Nazaraeans, the Gospel of the Ebionites), as well as the Gospel of the Egyptians and The Preaching of Peter. He adds various fragments of Gospels on papyrus. Then he lists a sequence of 'Birth and Infancy Gospels', including The Protevangelium of James and The Infancy Gospel of Thomas, followed by 'Gospels of the Ministry and Passion', including the Gospel of Thomas and The Gospel of Peter. He concludes Part I of his collection with a sequence of texts under the heading 'The Pilate Cycle'.

Wilhelm Schneemelcher's collection ${ }^{3}$ is still more elaborate, adding the Gospel of Philip and a variety of Gnostic Gospels, like The Gospel of Truth, the Pistis Sophia, and other Gospels attributed to the Apostles as a group, or under the name of an Apostle, or under the names of holy women, or attributed to an arch-heretic like Cerinthus or Marcion. We could add, for example, the Dialogue of the Saviour and the Apocryphon of James, not to mention the fairly recently discovered Gospel of Judas and the controversial Secret Mark.

So it is clear that our questions have point. Given that there were so many Gospels written in the first two centuries, why did historical Christianity limit the canonical Gospels to four? Why only four? Let me begin by setting the scene towards the end of the second century.

\section{Irenaeus settles the issue}

It has to be admitted that the issue in the second half of the second century was not as finalised as we might like to think. The credit for finalising the issue can be accorded to Irenaeus. In his great Against Heresies, he states definitively:

It is not possible that the Gospels can be either more or fewer in number than they are. For, since there are four zones of the world 
in which we live, and four principal winds ... it is fitting that she (the Church) should have four pillars, breathing out immortality on every side, and vivifying men afresh.

He goes on to give his famous identifications: of Matthew as a lion'symbolizing His [Jesus'] effectual working, His leadership, and royal power'; of Mark, 'like a calf, signifying His sacrificial and sacerdotal order'; of Luke, who'had, as it were, the face as of a man - an evident description of His advent as a human being'; and John 'like a flying eagle, pointing out the gift of the Spirit hovering with his wings over the Church' (adv. haer. III.11.8).

How was it that Irenaeus could be so emphatic on the point that there are only four Gospels worthy of consideration? He certainly knew of other views on the matter and devotes his major work to refuting them. But should we be so dismissive of these others? In several cases we do not have a copy of the text itself, only some scattered allusions and fragments - the Jewish-Christian Gospels being a significant case in point. Others, like the Gospel of Philip and the Gospel of Truth, draw on some Jesus tradition but have clearly been heavily influenced by Gnostic views - as evident, for example, in the Gospel of Truth's repeated emphasis on knowledge, as bringing enlightenment to those shrouded in a fog, lost in ignorance and darkness, drunk or sunk in a sleep. They show how the early Jesus tradition was elaborated by what became a strong second-century movement of thought which we generally put under the heading of Gnosticism, whose characteristic features cannot be traced back to Jesus. The opening words of the Gospel of Judas - 'the secret revelatory discourse in which Jesus spoke with Judas Iscariot for eight days, three days before he celebrated Passover' (Judas 33:1-6) - are typical of a message which cannot claim to be drawn from earlier Jesus tradition and can only attribute its teaching to Jesus by claiming that it was given secretly. ${ }^{4}$

The fact that so many of these documents were retained and are accessible to us only through the quotations and references made by Church Fathers probably tells its own story: that none of these documents made a wide and sustained appeal in the early centuries, in each case being treasured by only a few. The most interesting of them is the Gospel of Thomas, discovered in a complete form as part of the Gnostic library at Nag Hammadi in 1945-46. This contained a collection of 114 sayings attributed to Jesus, without narrative framework. What caught the attention was the substantial overlap between the Thomas sayings and the Synoptic tradition. Of the 114 Thomas sayings, 42 contain close parallel material to the Synoptic material. If the less-close parallels 
are included, that takes the comparable number to 63 sayings within Thomas' 114. Since the Thomas sayings usually include more material, the actual percentage of the parallel is less than 50 per cent; something over 50 per cent of Thomas' sayings lack parallel with the Synoptic tradition. That is still a significant number, and, not altogether surprisingly, there was a move to regard Thomas as of equal or nearly equal significance with the four canonical Gospels. Given the degree of parallel material, should not Thomas be set alongside Matthew, Mark, Luke and John and included in a revised New Testament? Thomas shows that we are not limited to the four New Testament Gospels; should we not include the Gospel of Thomas with them - a fifth canonical Gospel? ${ }^{5}$ Hence the questions which make up our title: Why four Gospels? Why only four?

It's when we look at Thomas' distinctive material that the questions begin to arise. ${ }^{6}$ First, Jesus is presented as 'the Living One'. His significance is that he brought saving revelation. Jesus' death and resurrection hardly feature. Thomas focuses almost exclusively on the revelation attributed to Jesus, his gospel introduced as 'the secret words which the living Jesus spoke and which Didymus Judas Thomas wrote down. ${ }^{7}$

Second, Thomas proclaims a characteristically Gnostic message. It speaks for those who believed that their true nature and spiritual home is different from their existence in this world. They have come from the light and have been caught in the corruption of the flesh. ${ }^{8}$ The problem addressed by Thomas is that so many are unaware of their true nature and origin, lacking knowledge of the contrast between their true nature and their present existence. ${ }^{9}$ Hence the characteristic Gnostic message: the good news is for those imprisoned in the fleshly physicality of this world, who need to be released by the knowledge of their true being and counselled on how to act now to ensure their return to that kingdom.

What a close study of the Gospel of Thomas reveals, then, is that whereas Thomas has taken over a good deal of the Jesus tradition which we find also in the Synoptics, Thomas' primary gospel is drawn from a different source. It is drawn from an analysis of the human condition which we do not find in the earlier Jesus tradition and offers a different solution. There are points of contact, of course; otherwise Thomas could not have drawn in as much Jesus tradition as it has. Themes of light and life provided a common currency. But the central message of Thomas was not that of Jesus or of the Jesus tradition, even though it could take over so much of the Jesus tradition. The basic narrative which 
holds the Thomas tradition together is distinctly other than what we find in the Jesus tradition of the New Testament. The distinctive message of Thomas comes from a source and an explanation of the human condition which is not to be found elsewhere in the Jesus tradition of the New Testament Gospels. The recognisable Jesus tradition in Thomas was essentially a bolt-on addition to a framework which originated from a different perception of reality from that of the Jewish scriptures which provided the context of both Jesus' message and that of the New Testament writers. In short, the basic narrative of Thomas is too distinctive and too different from the other first-century indications of the impact made by Jesus for us to find a root for the Thomas perspective in either Jesus' mission or the early Jesus tradition of the New Testament Gospels.

The historical reality, then, is that the Gospel of Thomas has probably made a bigger splash in the twentieth century than it did in the second. Our lack of knowledge of it prior to its discovery at Nag Hammadi in the 1940s strongly suggests that it did not have much impact in early Christianity. The fact that it never seemed even to occur to Irenaeus to include Thomas in his list of Gospels, even as a claim which had to be refuted, suggests that we have given Thomas far more status and significance than it actually achieved in the early centuries. At any rate Thomas does not require us to alter our main questions: Why four Gospels? Why only four? For us it is more interesting to know why Thomas was rejected.

\section{Why four?}

If one of the fascinating features of early Christianity is that the leaders refused to count as Gospels any more than four, it is equally interesting to know why they chose as many as four. Why not a single Gospel, proclaiming that there is only one gospel? 'This, and this alone is the true gospel'; 'This is the only message of salvation!' We know that there were indeed some attempts to come up with a single Gospel. Irenaeus tells us that Tatian 'separated himself from the church' and evidently returned to Syria, where he probably composed his Diatessaron, the first (preserved) harmony of the four canonical Gospels, dated probably in the period 170-175. It became the standard Gospel text in the Syriac-speaking churches till the fifth century, when it was replaced by the Peshitta version of the four separate Gospels, because its author had been dismissed as a heretic. Then there was Marcion, who wanted to split his version of Christianity away from the Old Testament, who took Paul as his great hero, 
and who accepted only one Gospel, a diminished version of Luke, setting aside Jesus' confession that the Maker of the universe is his Father. I confess to not a little unease when the Old Testament is so often bypassed and ignored in church services today, remembering that a direct line can be drawn from Marcion to the Holocaust. An alternative could well have been to focus on Matthew - Matthew who provided the basis for regarding Peter as the chief disciple and the rock on which the Church should be founded (Mt 16:18-19), in effect, the first pope. Should not Matthew be regarded as the Gospel?

The answer is no! Matthew's status certainly was very firm in a church which came to regard Peter as its first pope and Rome more and more as its central base; but in the first two centuries there were several different centres of the new movement. Mark, although little quoted in the second century, was probably saved by the historical memory of Mark's association with Peter, and perhaps as a collection of Peter's own teaching. Tatian had no hesitation in including Mark in his Diatessaron. Luke, as the first of a two-volume work, LukeActs, was too much associated with Paul to be passed over, despite Marcion, Paul being more famous even than Peter for his mission work in spreading the gospel to Gentiles. And John, not least by virtue of his somewhat uncertain identification with the disciple whom Jesus loved, ${ }^{10}$ though later than the other three Gospels, could hardly be set aside. And so we find, looking through the second century, that it is these four Gospels which are most often cited and drawn on, with others in comparison only rarely referred to. ${ }^{11}$ These, these four, were the Gospels.

An important and indeed decisive factor is given in the history of the word 'gospel.'The noun 'gospel, good news' (euangelion) is one of several terms which Christianity owes to Paul: 60 of its 76 occurrences in the New Testament appear in the Pauline corpus. Indeed, it is very likely that we owe the use of the word in Christian vocabulary to Paul. He probably derived it from the Hebrew verb, $b s r$, 'to bring good news', especially as used by Isaiah. Much reflected on, at Qumran ${ }^{12}$ and evidently by Paul, were two of Isaiah's verses:

Isaiah 52:7 - 'How beautiful upon the mountains are the feet of the messenger who announces (euangelizomenou) peace, who brings good news (euangelizomenos agatha), who announces salvation, who says to Zion, "Your God reigns".'

Isaiah 61:1 - 'The spirit of the Lord God is upon me, because the Lord has anointed me; he has sent me to bring good news (euangelisasthai) to the poor ...' 
And Jesus was evidently much influenced by the same passages if Luke's account of his preaching in the synagogue at Nazareth is anything to go by (Lk 4:16-21) - as is probably confirmed by the memory of his reply to the Baptist's query as to Jesus' mission: 'Tell John ... the blind receive their sight, the lame walk ... and the poor have good news brought to them (euangelizontai)' (Mt 11:5; Lk 7:22). So Paul was no doubt stimulated by both Isaiah and the Jesus tradition in drawing a noun from the verb, euangelion from euangelizesthai, a noun which summed up the good news brought by Jesus, which summed up the significance of what Jesus had done. Paul would also no doubt have been aware that the noun was used in his own day, usually in the plural and especially of the good tidings of Caesar's doings. But for Paul it was the singularity of the good news of Jesus which was the focus of his attention - the gospel.

What is interesting for us at this point is the fact that Mark takes over this word euangelion 'gospel' and uses it to sum up the story he was about to tell. He introduces his account of Jesus' ministry with the words, 'The beginning of the good news/the gospel of Jesus Christ' (Mk 1:1). It is as though he was reacting to Paul's use of the word to focus his message regarding Jesus' death and resurrection. Mark's reaction was in effect to say: the good news/the gospel of Jesus does not focus exclusively or entirely on his death and resurrection. Jesus' whole ministry - from his baptism by John, climaxing in his death and resurrection - is an integral part of the good news. And Mark emphasises the point in several places in his narrative, by inserting into the tradition of Jesus' teaching references to 'the gospel'. So, for example, he summarises Jesus' preaching as a call to 'repent', with the addition, 'and believe in the gospel' (Mk $1: 15) .^{13}$

So Mark marks the transition from the good news of Jesus' death and resurrection to the good news of his whole ministry. And indeed by introducing his account as 'The beginning of the gospel of Jesus Christ' (1:1), he also marks the beginning of the transition from the good news of Jesus' mission to the good news which is the account of that mission. Because of Mark's use of the term 'gospel' to sum up Jesus' mission, and his account of that mission, we can begin to speak of the Gospel of Mark. So it is to Mark in particular that we owe our understanding of the gospel as the good news of Jesus' ministry, climaxing in his death and resurrection. And as with Paul, it is always the singular, the good news focused on Jesus' mission climaxing in his death and resurrection.

And this is precisely the point where the canonical Gospels are to be distinguished from the so-called Gospels which came later. Matthew, Luke and 
John followed Mark's lead in presenting the good news of Jesus as an account of his ministry leading up to his passion and rising again, whereas the other Gospels that came later consistently focused on Jesus' teaching - as though the good news was primarily knowledge (gnōsis) that would dispel ignorance. Should they even be called 'Gospels'? Probably not, since it was Paul and Mark who gave the term its technical Christian meaning, as a summary reference to Jesus' mission climaxing in his death and resurrection - the good news for sinners, not just for the ignorant. And of the candidates for the title 'Gospel', only four, the canonical four, meet that qualification.

\section{Why four, when three are so similar?}

One of the most interesting things a student of the Gospels can do is to sit down with a synopsis of the Synoptic Gospels, the first three Gospels in the New Testament canon. In a synopsis the three Gospels are set down side by side, in three columns, with the same passages in the two or three Gospels set out in parallel. ${ }^{14}$ Some of these parallels are more or less word for word, one Evangelist either copying the other or both drawing on a common source. Others have much less word-for-word agreement, but it is the same story or teaching that has been recorded. When I studied the Synoptic tradition intensely years ago the phrase which kept coming to me was 'the same yet different.' Evidently it was the same story, the same teaching, but the Evangelist or his sources had told or used it differently. What also became clear was that often the chief point of the story or teaching was more or less word for word. But the introduction and the conclusion were different, more distinctive to the context in which the Evangelist was recording the tradition or to the point that he wanted to draw from it.

A classic example for me was the story of Jesus healing the centurion's servant, in Matthew 8:5-13 and Luke 7:1-10. It is clearly the same story that they are telling: the centurion asking for Jesus to minister to his sick slave; with the exchange between the centurion and Jesus being more or less word for word, climaxing in Jesus' amazement that 'not even in Israel have I found such faith' (Mt 8:10; Lk 7:9). And yet, the two tellings of the same story are different. In Matthew the centurion comes to Jesus personally to beseech his help, whereas in Luke the centurion does not come personally, counting himself as not worthy to meet Jesus face to face. The endings of the two accounts are different again, with Matthew incorporating some teaching from elsewhere in the Jesus tradition, before agreeing with Luke that the slave had indeed been healed. 
What do we learn from this, and from many other examples like it? We learn, first of all, that the Evangelists were not concerned to record the Jesus tradition with pedantic accuracy. They could draw from the same recalled episode in Jesus'life different lessons: here, for example, for Matthew it was a story of faith, for Luke a story of humility. Whether the centurion actually came personally to speak to Jesus or only sent some friends with his message was not very important. What mattered was that his plea for help and Jesus' response were retained word for word in the different tellings. It was the same story, but told differently - and so differently that the two accounts were technically irreconcilable. Did the centurion come personally, or did he not? That is a question which could trouble fundamentalists, but it evidently did not trouble Matthew or Luke.

This is precisely what we should expect, after all. The Jesus tradition was being recited and reflected on in many different parts of Palestine, Syria and modernday Turkey, etc. It was being interpreted and applied, different stories and teachings variously combined to provide instruction and guidance. Mark, for example, has clearly drawn on memories of a day in Jesus' life in 2:1-3:6. He goes on to provide a sequence of parables, including Jesus' rationale in telling so many parables $(4: 1-34)$, then a sequence of miracle stories set round the Sea of Galilee (4:35-5:43; 6:32-52). But through all these variants a clear picture of the one being remembered emerges. The impact made by Jesus on his first disciples is clearly evident in the stories they told and the teaching they rehearsed.

The distinctive message of each Evangelist is clearly to be seen, along with the different ways they wanted the good news of Jesus to impact the hearers when their Gospel was read to them.

\section{Mark}

A striking example is Mark's 'messianic secret'. ${ }^{15}$ Mark has, of course, no doubt that Jesus was Christ, the Messiah of Jewish expectation. And at the centre of his Gospel is Peter's confession of Jesus at Caesarea Philippi: 'You are the Messiah' (Mk 8:29). But it is clear that Jesus' function as Messiah was likely to be misunderstood. Indeed, when in response to Peter's confession in Mark's account, Jesus immediately begins to speak of his rejection and death (8:31), Peter takes him aside and begins to rebuke him (8:32). This is not what Peter had understood by messiahship. Mark reinforces the point that Peter, and all those he represented, had to change their ideas about Jesus' mission by quickly 
adding Jesus' two further predictions of his passion $(9: 31 ; 10: 33-34)$ and showing Jesus as resolute in his determination to go to Jerusalem (10:32).

It is presumably to prevent and avoid the misunderstanding, Peter's misunderstanding, of Jesus' messiahship as something lordly and triumphant, that Mark in his telling of the story maintains that Jesus kept his messiahship secret. Hence we have Jesus regularly commanding those healed by him to be silent. ${ }^{16}$ That too is Jesus' immediate response to Peter's confession (8:30). And after Peter's, James' and John's experience on the Mount of Transfiguration, Jesus immediately orders them to tell no one what they had seen until it could be understood in the light of Jesus' death and resurrection (9:9). Other indications of Mark's messianic secret are his emphasis on Jesus' desire to remain hidden, ${ }^{17}$ his noting that several of Jesus ' healings were performed in private, ${ }^{18}$ and the number of occasions when he indicates that Jesus gave his instructions to his disciples in secret. ${ }^{19}$

Another notable and distinctive feature of Mark's Gospel is his repeated use of the adverb 'immediately', far more than the other Evangelists. It is this which keeps the story moving and adds to its sense of excitement. For example, the fishermen called by Jesus 'immediately left their nets and followed him' (1:18). And when Jesus raised Jairus' daughter, 'immediately the girl got up and began to walk about' $(5: 42)$.

We should not fail to notice the distinctiveness of Mark's ending of his Gospel. Not unlike the other Evangelists, Mark climaxes his telling the story of Jesus with the report that the tomb where Jesus' dead body had been laid had been found empty, and further that 'a young man', presumably an angel, had announced that Jesus of Nazareth had been raised from the dead and would be encountered in Galilee (16:2-7). But the story then ends with a somewhat unexpected conclusion: 'So they went out and fled from the tomb for terror and amazement had seized them; and they said nothing to anyone, for they were afraid' $^{\prime}(16: 8)$. Of course, we can assume that Mark wanted to imply that the story did not end at that point and in that way. Of course his typical readers and audiences would know that the story went on to include them, and their experience of the risen Christ. But it is doubtful whether Mark's intention was as effective as he presumably intended. None of the other three Gospels followed his lead; their retellings climaxed in accounts of several appearances of the risen Christ. And those who used Mark itself were evidently less impressed by his ending than they should have been and added endings which echo those of the other Gospels, though these in effect miss what Mark intended. 


\section{Matthew}

The distinctiveness of Matthew's Gospel begins with the fact that he pushes the beginning of his account back from Jesus' baptism to his birth (Mt 1-2) and provides a fuller and better conclusion (28:1-20). Mark emphasised Jesus' role as a teacher, but Matthew provides more teaching. Rather strikingly, Matthew groups the teaching into five 'sermons', 20 the first prefaced with the note that Jesus went up a mountain $(5: 1)$. That this echo of the five books of Moses was no doubt deliberate is confirmed by Matthew's note that the infant Jesus' escape from Herod to and from Egypt was to fulfil the words of Hosea (Hos 11:1): 'Out of Egypt have I called my son' (Mt 2:15). Equally notable is the way Matthew uses the first of Jesus' sermons to affirm the law, with a strength which would probably have surprised Paul and Mark: 'until heaven and earth pass away, not one letter ... will pass from the law until all is accomplished. Therefore, whoever breaks one of the least of these commandments and teaches others to do the same, will be called least in the kingdom of heaven' (5:17-20). Evidently Matthew had no qualms in presenting Jesus as a new Moses. Equally distinctive of Matthew on the same point are Jesus' repeated warnings against anomia, 'lawlessness,',21 a term which appears only in Matthew. And part of the same concern of Matthew is his account of repeated occasions in which he depicts Jesus as redefining the law in dispute with Pharisees. ${ }^{22}$ Evidently Matthew retells his story of Jesus in a post-70 situation in which the Pharisees were the principal Jewish leadership to have survived the disaster of Israel's war with Rome and were beginning to redefine Israel's calling round the Torah.

An equal concern of Matthew was to emphasise that Jesus was the fulfilment of Jewish hope and expectation. Here we should certainly notice the distinctively Matthean insistence that 'All this took place to fulfil what had been spoken by the Lord through the prophet', going on, in the first case, to cite Isaiah 7:14 (Mt 1:22-23). The same note becomes a repeated and distinctive emphasis throughout Matthew's Gospel: this happened to fulfil what had been spoken by the prophet. ${ }^{23}$ More striking is the distinctive Matthean emphasis that Jesus embodied the divine presence. This is signalled in the first chapter by the quotation from Isaiah 7:14:'Behold, the virgin shall conceive and bear a son, and they shall name him Emmanuel', to which Matthew adds the explanation, 'which means "God is with us"' (Mt 1:23). And it is reinforced thereafter by Matthew's portrayal of Jesus as not only the bearer of wisdom but to be identified with divine Wisdom. Where Jesus ben Sira bids his readers, 'Put your neck under Wisdom's yoke, and let your souls receive instruction' 
(Sir 51:26), Jesus ben Maria, Matthew's Jesus, says, 'Take my yoke upon you and learn from $m e^{\prime}$ (Mt 11:28). ${ }^{24}$

Equally striking and distinctive of Matthew is the degree to which Israel was the focus of his mission. The opening prediction that Mary will bear a son has the added instruction: 'You are to name him Jesus, for he will save his people from their sins' (1:21). And the initial mission of Jesus' chosen twelve disciples begins with the striking note: 'Go nowhere among the Gentiles, and enter no town of the Samaritans, but go rather to the lost sheep of the house of Israel' (10:5-6). Equally striking is Jesus' initial response to the Canaanite woman's plea for help: 'I was sent only to the lost sheep of the house of Israel' $(15: 24) .{ }^{25} \mathrm{We}$ should add though that even more distinctive of Matthew's portrayal of Jesus is his consistent emphasis on Jesus' openness to Gentiles. He begins with a genealogy in which the only three women named (Tamar, Rahab and Ruth) are all Gentiles (1:3-6). He begins his account of Jesus' mission with the Baptist warning his audience not to rely on the fact that Abraham was their ancestor (3:9), and reports Jesus as warning that the heirs of the kingdom may well be thrown into outer darkness (8:11-12). Further on, Matthew has Jesus warning that the kingdom of God will be taken away from Israel and given to a people who produce the fruits of the kingdom (21:43; similarly 22:8-9). And he concludes his Gospel with Jesus giving the great commission to make disciples of all nations (28:19; see also 24:14). So a Jewish Gospel intent that the good news of Jesus was for Gentiles as well is a good classification of the Gospel according to Matthew.

\section{Luke}

Luke tells the same story, but again with his own distinctive emphases. For example, every so often he inserts the note that Jesus was praying: at his baptism in the Jordan (3:21); he withdrew into the wilderness to pray (5:16); he spent all night in prayer before choosing the twelve disciples (6:12-13); he went up the mountain, and it was as he prayed that he was transfigured (9.28-29). Again Luke does not refrain from referring to Jesus as 'Lord' in his own telling of the story, but the first time any of Jesus' disciples refers to Jesus as 'Lord' in his narrative is after Jesus' resurrection (24:34). Equally striking is Luke's emphasis on the Spirit: the Spirit inspires those referred to in the birth narratives; ${ }^{26}$ but Luke does not hesitate to emphasise that Jesus went to his period of temptation at the leading of the Spirit and that he returned from that time of testing 'in the power of the Spirit' $(4: 1,14)$. And it is Luke alone who shows Jesus beginning his preaching in Nazareth's synagogue with the citation 
from Isaiah 61:1: 'The Spirit of the Lord is upon me, because he has anointed me to preach good news to the poor' (Lk 4:18). Again, it is only Luke who records Jesus as rejoicing in the Holy Spirit (10:21), and only Luke who shows Jesus as emphasising that the heavenly Father is keen to give the Holy Spirit to those who ask him (11:13).

Equally distinctive of Luke is his emphasis that Jesus' mission was to and for the benefit of sinners. It is summed up nicely in his introduction to the three parables of the lost things/people: 'The Pharisees and the scribes murmured, saying, "This man receives sinners and eats with them"' (15:2). This is also emphasised in the parable of the Pharisee and publican, which only Luke records, in which the effective prayer is that of the publican saying, 'God, be merciful to me a sinner' (18:13); and again in Luke's distinctive account of Jesus' readiness to go to be guest of Zacchaeus, a man whom the crowds dismiss disdainfully as a 'sinner' (19:7). ${ }^{27}$ Again distinctive of Luke's Gospel is his emphasis that the gospel is good news for Gentiles. The note is struck already in Simeon's paean of praise in the Gospel's introduction: 'Mine eyes have seen thy salvation ... a light for revelation to the Gentiles' (2:30-32). It is only Luke who, in describing the mission of John the Baptist, rounds off the quotation from Isaiah 40 with the words, 'and all flesh shall see the salvation of God' (Lk 3:6). And only Luke extends Jesus' preaching in the synagogue in Nazareth to remind his hearers that Elijah and Elisha ministered to Gentiles (4:25-27). Nor should we forget that it is only Luke who recalls Jesus' parable of the good Samaritan (10:30-35), and only Luke who tells the story of the ten lepers healed by Jesus, of whom only one returned to give Jesus thanks - 'Now he was a Samaritan' (17:11-19).

Nor should we forget that it is particularly in Luke's Gospel that we see Jesus' concern for the poor and recognition of the perils of power and wealth. Already in the first chapter, Mary's hymn praises God who 'has filled the hungry with good things, and the rich he has sent empty away' (1:53). It is in Luke that we find the first beatitude, 'Blessed are you poor', complemented by the first woe, 'Woe to you that are rich' $(6: 20,24)$. It is only Luke who records the parable of the rich fool (12:13-21), and Jesus' instruction that when a banquet is to be given those invited should be the poor, the maimed, the lame, the blind (14:12$14,21)$. And only Luke who tells the story of the rich man who feasted sumptuously every day and of the poor man, Lazarus, who lay at his gate uncared for (16:19-31). ${ }^{28}$ Not least, we should not forget that it is Luke who particularly notes the role of women in Jesus' ministry. Women are prominent in the opening birth narratives (Lk $1-2$ ). It is only Luke who recalls the women, 
Mary Magdalene, Joanna, Susanna and many others who gave active support and financial help to Jesus in his mission (8:1-3); and only Luke who tells the story of Mary and Martha (10:38-42). Luke alone records Jesus' observation that it was only because of a widow's persistence in asking for justice that an unrighteous judge vindicated her (18:1-8); and Luke alone records Jesus' concern for the 'daughters of Jerusalem' who stayed faithful to Jesus on his final journey to Golgotha (22:27-29).

In short, what this brief survey clearly reveals is that the story of Jesus could be told differently; that the same account of Jesus could be told in various ways and with differing emphases. The Synoptics richly illustrate the same motif the same, yet different. This, we might note, underlines the dangers of a fundamentalist approach which wants to stick rigidly to the text and which warns against any diversion from it. On the contrary, the Synoptic accounts show how variously the story of Jesus could be told, and how the same story could be differently expressed. The proper conclusion is not that these are the only ways that the story of Jesus should be told, but rather that they illustrate the diversity of the ways in which the good news of Jesus should be circulated. If these were the different ways in which the same story could be told, then what does that say to us now about how differently the same story may be told today?

And the same point is re-emphasised by our fourth New Testament Gospel the Gospel of John.

\section{Why is John so different?}

Many people assume that John is a Gospel just like the Synoptics. They do not seem to be aware of how different John is from the Synoptics. Let me remind you of how different John's Gospel is. For example:

- In the Synoptic tradition Jesus is remembered as speaking typically in aphorisms and parables. In contrast, in John, Jesus engages in lengthy dialogues and circuitous discussions and does not use parables. ${ }^{29}$

- In the Synoptics the central theme of Jesus' preaching is the kingdom of God, whereas in John the kingdom of God hardly features in Jesus' speech. ${ }^{30}$ 
- In the Synoptics Jesus speaks little of himself, whereas in John Jesus speaks much of himself, notably in the striking 'I am' statements ('I am the bread of life' - John $6: 35,48 ;{ }^{\prime}$ I am the light of the world' - 8:12; 'Before Abraham was, I am' - 8:58;'I am the resurrection and the life' - 11:25; etc), which have only weak parallels in the Synoptics.

- In the Synoptics Jesus speaks of repentance and forgiveness quite often but speaks only occasionally of eternal life. In contrast, in John Jesus speaks of repentance and forgiveness only once (20:23) but speaks regularly of eternal life.

Confronted by such differences it is not credible to explain them simply by assuming that the Evangelists drew differently from a wider and more generally known Jesus tradition. Is it credible to argue that the Synoptics completely ignored the lengthy dialogues which John uses, and also most of the Johannine Jesus' talk of eternal life, while John ignored almost all of the tradition of Jesus speaking about the kingdom of God, even though it was the principal theme of Jesus' preaching according to the Synoptics? Above all, is it credible to assume that the Synoptic tradition was unaware of the great Johannine 'I am' assertions or ignored them? Quite frankly, the only obvious answer to both questions is No! John certainly retains the Gospel format first given by Mark, beginning with Jesus' encounter with the Baptist and climaxing in the Cross and Resurrection. But evidently he saw his task as different from that of the Synoptics - not so much simply to recall what Jesus had said and done during his mission, but to bring out the significance, we could justifiably say the sign-ificance of Jesus' mission. ${ }^{31}$

He does this partly by giving further emphasis to what the Synoptics had already claimed for Jesus. That Jesus is Messiah is a more central theme in John than in the Synoptics. In the opening chapter he is already acclaimed Messiah by Andrew in speaking to Peter (1:41). In speaking to the Samaritan woman whom he encountered at the well, Jesus confesses to be Messiah (4:25-26). Jesus' messiahship is debated throughout the second half of John 7. To affirm that Jesus is Messiah has already become a ground for expelling someone from the synagogue (9:22). Martha confesses Jesus as Messiah in 11:27. And John states as his reason for writing his Gospel'so that you may come to believe that Jesus is the Messiah' (20:31). So John greatly strengthens that motif.

Even more he strengthens the theme of Jesus as the Son of God. In a unique phrase, he emphasises that Jesus is 'the one and only Son'.32 And in John God 
as Jesus' 'Father' is vastly more prominent than in the Synoptics. ${ }^{33}$ Equally striking are the distinctive notes in John. The Baptist testifies, 'I have seen and have testified that this is the Son of God' (1:34). In the same opening chapter, Nathanael confesses, 'Rabbi, you are the Son of God!' (1:49). Martha's full confession is, 'I believe that you are the Messiah, the Son of God' (11:27). And a consistent note throughout John is that Jesus has been authorised and sent by the Father. ${ }^{34}$

If these christological assertions are shared with the Synoptic Evangelists, but strengthened by John, a further Johannine emphasis is quite distinctive. It is that Jesus not only brought the word from God, he was the Word of God incarnate. John makes this clear in the Prologue to the Gospel. Unlike Matthew and Luke he begins not with the birth of Jesus, but with the Logos (Word) as the agent of creation. 'In the beginning was the Word, and the Word was with God, and the Word was God ... All things came into being through him', climaxing in, 'And the Word became flesh and lived among us, and we have seen his glory, the glory as of a father's only son, full of grace and truth' (1:1, 14). The genius of this identification was that Logos was familiar to both Jew and Greek. Jews were long accustomed to their scriptures' talk of the word coming to patriarch and prophet, and of the heavens made 'by the word of the Lord' (Ps 33:6). And in Greek thought logos was a term ideally suited to refer with equal facility both to the word unexpressed and the word expressed. This is what the term enabled John to indicate: that Jesus was the mind of God expressed, expressing the inexpressible and making the unknowable known. John used it to indicate not simply that Jesus brought the word from God, like the prophets of old, but that the word became flesh in Jesus. No one had ever made such a claim before. It took the gospel into a new dimension, addressing minds trained in Greek philosophy, challenging them to a degree that surpassed all that Hellenistic Judaism had attempted thus far. This was not an Evangelist simply trying to preserve and pass on what Jesus and the first disciples had first proclaimed. This was an attempt to draw out the full significance of Jesus for a different and more sophisticated audience. It is John 1:14 that shows most clearly that John was not content simply to provide another Synoptic recollection of Jesus' ministry. His aim was to show that Jesus spoke not simply to Jewish teachers and disciples but also to minds seeking to explore what the true reality of the world was. But he did it, we should not forget, within the framework of a mission of Jesus which began with John the Baptist and climaxed in his death and resurrection. This is gospel indeed, not simply looking back, but looking forward to new audiences, and not simply 
repeating the Jesus tradition already established by the Synoptic Evangelists, but seeking to re-express it for a new and changing audience.

Somewhat surprisingly John did not extend the Logos Christology explicitly through the rest of his Gospel. Instead he developed the equivalent thought of Jesus as the embodiment of divine Wisdom. This was a more familiar Jewish way of speaking of God's interaction with his creation and his people - more familiar particularly in Jewish Wisdom tradition. Thus Proverbs 3:19-'The Lord by wisdom founded the earth' - and the great Wisdom hymn of Proverbs 8 , where Wisdom declares: 'When he established the heavens, I was there ... Then I was beside him, like a master worker' $(8: 27,30)$. Most striking is the way Wisdom is explicitly identified with Israel's scriptures. In ben Sira (Ecclesiasticus), 'Wisdom praises herself' and there follows a hymn in praise of Wisdom, climaxing in the identification: 'All this is the book of the covenant, the law' (Sir 24:1, 23). Similarly in Baruch, a lengthy hymn in praise of divine Wisdom (Bar 3:9-37) concludes: 'She (Wisdom) is the book of the commandments of God, the law that endures for ever' (4:1).

In John the echoes of what is said about Wisdom are frequent. Wisdom 9:1718 celebrates how Israel 'was saved by wisdom', and John celebrates that God 'sent his Son in order that the world might be saved' (Jn 3:17). Ben Sira rejoices that Wisdom will give those who fear the Lord 'the water of wisdom to drink' (Sir.15:3), and Wisdom affirms that 'Those who eat of me will hunger for more, and those who drink of me will thirst for more'. In John 4, Jesus says to the woman at the well,'Those who drink of the water that I will give them will never be thirsty' (4:14). In Proverbs Wisdom makes the invitation, 'Come, eat of my bread and drink of the wine that I have mixed', and ben Sira gives assurance that 'She [Wisdom] will feed him with the bread of learning, and give him the water of wisdom to drink' (Sir 15:3). What else can the Johannine Jesus be referring to when he gives his invitation in similar terms:'I am the bread of life. Whoever comes to me will never be hungry, and whoever believes in me shall never be thirsty' (John 6:35)? That the Johannine Jesus is presented as the incarnation of divine Wisdom is even more apparent than that he is the Word become flesh.

There are several other distinctively characteristic emphases of John's presentation of Jesus which should not escape notice. It is in John that Jesus gives his disciples a new commandment: 'that you love one another, just as I have loved you' (13:34-35). ${ }^{35}$ Distinctively Johannine is his individualism: each eats Jesus' flesh and drinks his blood (6:53-58); each believer drinks the water he gives 
(7:37-38); each sheep hears his voice $(10: 3-4,16)$; each branch is rooted in the vine (15:4-7). The Johannine Jesus emphasises to the woman at the well that worship is not tied to a specific cultic centre:'The hour is coming when you will worship the Father neither on this mountain nor in Jerusalem ... But the hour is coming, and is now here, when the true worshippers will worship the Father in Spirit and in truth' (4:21-23). Notably there is no mention of apostles or prophets or teachers. Instead Jesus quotes Isaiah 54:13: 'They shall all be taught by God' (Jn 6:45). And the promise of the Spirit is that 'he will teach you everything, and remind you of all that I have said to you' (14:26). Even more noticeable is the fact that John seems to play down Jesus' baptism and last supper, passing over each without mention, and that he qualifies the great bread of life discourse in chapter 6 with the terse reminder that 'It is the Spirit that gives life; the flesh is useless. The words that I have spoken to you are spirit and life' (6:63). It is this absence of reference to what were presumably already well-established features of corporate church gathering and worship which has suggested to some that John practised and commended what later would be called conventicle Christianity, a less structured and more individualistic worship.

In the light of these distinctive features the question inevitably arises whether John in his reworking of the Jesus tradition went too far. The question is reinforced by the fact that John's Gospel appealed to the Gnostics more than did the others - the Gnostics working with a sharp polarisation of flesh and spirit, seeking for delivery from physical fleshliness, and assuming that salvation could only mean release from the flesh. So the question arises whether John, in his representation of the good news of Jesus, overemphasised Jesus' divinity and played down his humanity. Did he so emphasise Jesus' divinity that his humanity was only apparent? The answer is a definite No! The emphasis of John 1:14 is clear: 'the Word became flesh'. John did not say what the Gnostics would have liked: that the Word appeared as flesh, in fleshly guise. No! 'The Word became flesh.' Those who have accused John of 'naive docetism', putting the primary emphasis on the following clause - 'and we have seen his glory, the glory as of the Father's only Son'36 - have ignored or played down John's primary emphasis. The glory that was seen was that of the incarnate Jesus, the Word become flesh, whose ministry climaxed in his death, a genuine death, and his resurrection. That was his glory. ${ }^{37}$

All this shows someone who was prepared to take some risks to ensure that the gospel is heard to speak to all conditions and situations. This was an attempt to speak meaningfully well beyond the original context of Jesus' mission, an attempt to show that the gospel of Jesus was immediately relevant 
to those caught up in the fashionable philosophising of the day. It was dangerous, as the history of John's acceptance within the New Testament canon clearly shows. The fact that the first known commentary on John was written by the Gnostic Heracleon in the latter half of the second century is a clear indication that John drew very near to the boundary which other and later treatments of Jesus transgressed. But it was precisely his insistence in John 1.14, that the Word became flesh, and his presentation within the structure provided by Mark, climaxing in Jesus' death and resurrection, which ensured that John was retained within emerging Christianity as what we might call a canonical restatement of the gospel.

The interesting question which John raises, then, is this: which is the best precedent for today - the Synoptics' presentation of Jesus, or John's?

\section{Conclusion}

So the answers to our questions become clear. Why four Gospels? Why only four?

First answer: why four Gospels? Because the term 'gospel' was given its distinctive definition by Paul focusing on Jesus' death and resurrection. Mark expanded that definition to include the mission of Jesus climaxing in Jesus' death and resurrection. And the other Evangelists who followed suit were deemed to define and express the good news of Jesus definitively.

Second answer: why four Gospels? Because the Synoptic Gospels showed that the gospel could not be confined to one format or version. The Synoptic Gospels showed that integral to the gospel focused on Jesus is its character as the same yet different. To limit the story of Jesus as though only one version is authentic is to strangle it. The Synoptics highlight the danger of a fundamentalist approach, as though only one version could be truly authentic. They show that even when the gaze is directed backwards, what is to be clearly seen is that Jesus - the same Jesus - was remembered differently, and that the story of Jesus could be told diversely, even when sticking to the gospel form.

Third answer: why a fourth Gospel? Why John? Because John shows how far the 'same yet different' formula could be extended. John shows that in reaching out to audiences further removed from the Palestinian context of the Synoptics' accounts there has to be a bold restatement of the gospel. To reach a more diverse and diversely educated audience there has to be some willingness to 
take risk - to retell the story of Jesus in terms which might be misinterpreted, but with the climactic account of Jesus' death and resurrection always as ensuring that the feet remain firmly on the ground.

Fourth answer: why only four Gospels? Because the four Gospels - Mark Matthew, Luke and John - quickly established themselves as the authoritative records of Jesus' ministry, and became definitive of what a written Gospel should be. And because others which followed, like the Gospel of Thomas, precisely by neglecting the character of a Gospel as a 'passion narrative with an extended introduction', effectively gave up the claim to be rightly called a 'Gospel'.

These answers should be important for Methodists, not simply because they show how justified John Wesley was in seeking to bring the gospel to those whom it had passed by, and to bring it out in faithfulness to its essential character. But also because they provide a challenge to all Christians today Methodists included - to bring out the relevance of the good news of Jesus to the changing circumstances of today, just as the New Testament Evangelists sought to demonstrate how clearly and fully the good news of Jesus spoke to their own day. This is the wisdom and strength of our New Testament with its four Gospels, providing both an example of how diversely the same gospel could be told, and a challenge to us to retell the good news of Jesus today with equal or equivalent effect.

\section{Notes}

1. See his letter to Ebenezer Blackwall, dated 20 December 1751.

2. J. K. Elliott, The Apocryphal New Testament, Oxford: Clarendon Press, 1993.

3. Wilhelm Schneemelcher, New Testament Apocrypha: Vol. 1, Gospels and Related Writings, trans. R. McL. Wilson, Cambridge: James Clarke, 1991.

4. For further detail and discussion, see my Christianity in the Making: Vol. 3, Neither Jew Nor Greek: A Contested Identity, Grand Rapids, MI: Eerdmans, 2015, §§44.444.8. I will refer to it as CiM 3.

5. So, for example, R. W. Funk and R. W. Hoover, The Five Gospels: The Search for the Authentic Words of Jesus, New York: Macmillan, 1993; S. J. Patterson et al., The Fifth Gospel: The Gospel of Thomas Comes of Age, London:T \& T Clark, 2011.

6. In what follows I draw on CiM 3, §§43.2-5. Most helpful are the two works by A. D. DeConick, Recovering the Original Gospel of Thomas: A History of the Gospel and its Growth, LNTS 286, London: T \& T Clark, 2005, and, The Original Gospel of Thomas in Translation, LNTS 287, London: T \& T Clark, 2006.

7. Gospel of Thomas Incipit, 52, 59, 111.

8. In CiM 3, pp. 392-393, I cite Thomas 3:3-4, 18, 19:1, 49, 50, 67, 83, 84, 111:2-3.

9. In CiM 3, pp. 393-394, I cite Thomas 3:5, 28, 29, 56, 70, 80, 87, 112. 
10. John 13:23; 19:26; 20:2; 21:7, 20.

11. There are surprisingly few indications that Mark was known and used. This is in large part because Mark had been almost wholly absorbed by Matthew, so that allusions to Mark are hard to distinguish from allusions to the more popular Matthew. Even so quite a number of allusions to Mark are evident; see CiM 3, $\S 44.8 \mathrm{a}$.

12. Note particularly $11 \mathrm{Q}$ Melch $2: 15-24$ and $4 \mathrm{Q} 521$.

13. See also Mark 8:35 and 10:29; and further CiM 3, pp. 193-194.

14. B. H. Throckmorton, Gospel Parallels: A Synopsis of the First Three Gospels, New York: Thomas Nelson, 1957, is the classic English text. K. Aland, Synopsis Quattuor Evangeliorum, Stuttgart: Deutsche Bibelgesellschaft, 1988, is the standard fourfold Gospel synopsis.

15. This was first noted by W. Wrede, The Messianic Secret, 1901, ET Cambridge: James Clarke, 1971. See further my 'The Messianic Secret in Mark', Tyndale Bulletin 21 (1970), pp. 92-117, reprinted in C. M. Tuckett (ed.), The Messianic Secret, London: SPCK, 1983, pp. 116-131.

16. Mark 1:34, 43-45; 3:11-12; 5:43.

17. Mark $1: 35,45 ; 3: 7,9 ; 6: 46 ; \ldots$

18. Mark $5: 37,40 ; 7: 33 ; 8: 23$.

19. Mark 4:34;6:31-32; 7:17; 9:2, 28-29; 13:3.

20. Matthew $5: 3-7: 27 ; 10: 5-42 ; 13: 3-52 ; 18: 1-35 ; 24: 2-25: 46$ - all with the same ending.

21. Matthew $7: 23 ; 13: 41 ; 23: 28 ; 24: 12$.

22. Matthew 5:20-22, 27-28; 7:12; 9:13 and 12:7 (Hos 6:6); 15:17-20; 22:37-40; 23:23,$33 ; 24: 20$.

23. Matthew 2:15, 23; 4:14-16; 8:17; 12:17-21; 13:14, 35; 21:4; 26:54, 56; $27: 9$.

24. See also Matthew $11: 19$ and 23:34, 37-38.

25. See also Matthew 2:6 and 19:28.

26. Luke $1: 15,17,35,67 ; 2: 25-27$.

27. See also Luke 5:8, 30, 32; 7:34, 37, 39; 15:7, 10.

28. See also Luke $4: 18 ; 12: 33 ; 18: 22-25 ; 19: 8-9$.

29. The nearest is John 15:1-6-'I am the true vine.'

30. References to the 'kingdom': Matthew 47x; Mark 18x; Luke 37x; John 5x, in only two passages (John 3:3-5; 17:2-3).

31. John thinks of Jesus' miracles as 'signs' (notably John 4:54; but see also 2:18; 6:14, 30; $10: 41 ; 12: 18)$.

32. John $1: 14 ; 3: 16,18$.

33. J. Jeremias, The Prayers of Jesus (1966), ET London: SCM Press, 1967, provides the striking statistics for reference to God as 'Father' in the words of Jesus - Mark 3, Q 4, special Luke 4, special Matthew 31, John $100(30,36)$.

34. John $3: 17,35 ; 5: 19,26,30 ; 6: 38 ; 12: 49-50 ; 14: 31$.

35. See also John 14:21; 15:10, 13.

36. I refer to a notable attempt by E. Käsemann, The Testament of Jesus (1966), ET London: SCM Press, 1968, p. 26.

37. Glory is a particular theme of John's Gospel - doxa 18x, doxazein 23x. 